\title{
Concentration-dependent effects of narciclasine on cell cycle progression in Arabidopsis root tips
}

\author{
Xiaofan $\mathrm{Na}^{\dagger}$, Yanfeng $\mathrm{Hu}^{\dagger}$, Kun Yue, Hongxia Lu, Pengfei Jia, Huahua Wang, Xiaomin Wang and Yurong Bi
}

\begin{abstract}
Background: Narciclasine (NCS) is an Amaryllidaceae alkaloid isolated from Narcissus tazetta bulbs. NCS has inhibitory effects on a broad range of biological activities and thus has various potential practical applications. Here we examine how NCS represses plant root growth.

Results: Results showed that the inhibition of NCS on cell division in Arabidopsis root tips and its effects on cell differentiation are concentration-dependent; at low concentrations (0.5 and $1.0 \mu \mathrm{M})$ NCS preferentially targets mitotic cell cycle specific/cyclin complexes, whereas at high concentration $(5.0 \mu \mathrm{M})$ the NCS-stimulated accumulation of Kip-related proteins (KRP1 and RP2) affects the CDK complexes with a role at both G1/S and G2/M phases.

Conclusions: Our findings suggest that NCS modulates the coordination between cell division and differentiation in Arabidopsis root tips and hence affects the postembryonic development of Arabidopsis seedlings.
\end{abstract}

\section{Background}

The growth and development of multicellular organisms depends on the spatiotemporal coordination of cell proliferation, cell differentiation, and subsequent cell specialization [1]. During plant postembryonic development, meristematic tissues provide new cells for growth at both ends of the main body axis. Stem cells in the root meristem generate transit-amplifying cells, which undergo additional divisions in the proximal meristem, and differentiate in the meristem transition zone that encompasses the boundary between dividing and expanding cells in different cell files. The balances between cell proliferation, cell cycle arrest and differentiation to maintain the organogenetic program depend on the coordination of gene expression, posttranslational modification, and specific proteolysis of cell cycle regulators. The retinoblastoma (RB)-E2F pathway is one of the most important regulatory pathways that control and couple cell division and cell differentiation $[2,3]$. The E2F and DP proteins interact to form active transcription factors that bind to various gene promoters and regulate the expression of genes required for cell cycle progression. The RB protein

\footnotetext{
* Correspondence: yrbi@|zu.edu.cn

† Contributed equally

School of Life Sciences, Lanzhou University, Lanzhou 730000, People's Republic of China
}

binds to E2F proteins, masking the transactivation region and blocking the transcriptional activity. This repression can be released by phosphorylation of the RB protein, catalyzed by cyclin-dependent kinases (CDKs), and formation of a functional E2F-DP heterodimer [2,4-8].

The CDK activity can be modulated by several mechanisms, including phosphorylation, cyclin degradation, or association with CDK inhibitory proteins [9-12]. CDK inhibitory proteins have also been proven to be important regulators of the endo-reduplication cycle in several organisms. Proteins related to the class of mammalian Kip/Cip CDK inhibitors have been identified in plants and designated Kip-related proteins (KRPs) [13,14]. Despite the low sequence homology with their mammalian counterparts, KRPs are bona fide functional orthologs of the Kip/Cip proteins that are capable of inhibiting the CDK activity both in vitro and in vivo [13,15-18].

Amarallidacae alkaloids are widely present in the plant kingdom and have important biological properties such as acetylcholinesterase inhibitory activity, cytotoxicity, antitumoral activity and so on [19]. Narciclasine (NCS) is an Amaryllidaceae alkaloid isolated from Narcissus tazetta bulbs and also exists in the genera Galanthus, Haemanthus, Leucojum, Pancratium, Sprekelia, Sternbergia and Vallota [20]. Previous studies showed that NCS possesses antimitotic [21] and antiviral functions 
[22], inhibits protein synthesis in rabbit reticulocyte and yeast cell-free systems [23], induces apoptosis-mediated cytotoxicity in certain human cancer cells [24] and activates Rho and stress fibers in glioblastoma cells [25]. McLachlan et al. showed that pancratistatin, of which the chemical structure is very close to NCS, induces rapid apoptosis in SHSY-5Y neuroblastoma cells at pharmacologic doses [26]. These pervious researches mainly focus on the anticancer potential of NCS, but show little interest in its function in plants. More recently, a broad range of inhibitory effects of NCS in plant were found, including inhibition of seed germination and seedling growth in rice and Chinese cabbage [27]; and accumulation of chlorophylls and chloroplast proteins in wheat [28]. However, little is known about the mechanism of NCS action in plant cells. In the present study, we provide evidence that NCS inhibits postembryonic development by affecting the balance between cell division and differentiation in Arabidopsis root tips.

\section{Results}

\section{Effects of NCS on postembryonic development of} Arabidopsis roots

To study the effects of NCS on the development of Arabidopsis, we first tested the effects of various concentrations of NCS on the germination rate of wild type (WT) Arabidopsis seeds. After $84 \mathrm{~h}$ continuous monitoring, we found that NCS significantly delayed the radicle emergence and seed germination. In the control medium, more than $80 \%$ of the Arabidopsis seeds germinated within $36 \mathrm{~h}$, but in the medium containing 1.0 or $5.0 \mu \mathrm{M}$ NCS only about $20 \%$ of the seeds germinated in $36 \mathrm{~h}$ (Figure 1A). In addition, the seedling growth was significantly inhibited by $5.0 \mu \mathrm{M}$ NCS (Figure 1B and 1C). The root growth ceased after germination and primary roots only grew to about 1.0 to $2.0 \mathrm{~mm}$ in the presence of $5.0 \mu \mathrm{M} \mathrm{NCS}$ (Figure 1C). These results indicate that NCS inhibits radicle elongation.

To further dissect the role of NCS in postembryonic development, we examined the effects of NCS on the primary root elongation and lateral root density. As shown in Figure 1D, the primary root growth was inhibited by NCS at as low as $0.1 \mu \mathrm{M}$, and $5.0 \mu \mathrm{M}$ NCS almost completely inhibited the primary root growth. The relative growth rate of primary roots was also greatly inhibited after transfer to NCS (Additional file 1: Figure S1A). The lateral root density was not affected by 0.1 or $0.5 \mu \mathrm{M}$ NCS, but was inhibited about $21.2 \%$ by $1.0 \mu \mathrm{M}$ NCS, and was nearly completely inhibited by $5.0 \mu \mathrm{M}$ NCS (Figure 1E).

Plant morphogenesis relies on regulated cell division and directed cell expansion [29]. To examine whether NCS affects cell division or cell expansion, we examined cells in primary roots using confocal microscopy. As shown in Figure $1 \mathrm{~F}$ and ${ }^{\mathrm{Q} 2}$ Additional file 1: Table S1, cells in the meristem of NSC-treated roots were larger than those in control roots, indicating NCS stimulates cell expansion in the meristem zone. The number of dividing cells in root tips was greatly decreased compared to the control (Figure 1F) and the mitotic index in the meristem zone of Arabidopsis roots was also reduced (Additional file 1: Figure S1B) after NCS treatment, suggesting that NCS inhibits cell proliferation in Arabidopsis roots. The results also showed that the vascular bundle gradually extended from the upper zone to the bottom part of roots after 0.5 and $1.0 \mu \mathrm{M}$ NCS treatment (Figure 1F and Additional file 1: Figure S2). However, 5.0 $\mu \mathrm{M}$ NCS treatment did not show this phenotype. It means that low concentration of NCS may stimulate cell differentiation in root tips.

To further confirm the effects of NCS on cell differentiation, the expression of selected Arabidopsis GAL4 enhancer trap transactivation line J0121 in the meristem zone was investigated. After 0.5 or $1.0 \mu \mathrm{M}$ NCS treatment for 2 days, the expression of GFP increased in root tips, suggesting that the differentiation of pericycle cells was stimulated (Figure 2A). During the differentiation of vascular cells (Figure 1F and Additional file 1: Figure S2), root hairs emerged from epidermal cells in the apical region of NCStreated roots but not control roots (Figure $2 \mathrm{~B}$ and $2 \mathrm{C}$ ), suggesting that NCS can stimulate the development of root hairs in Arabidopsis root tips. These observations suggest that 0.5 or $1.0 \mu \mathrm{M}$ NCS may directly or indirectly stimulate cell differentiation in proliferating tissues. With $5.0 \mu \mathrm{M}$ NCS treatment, the expression of GFP decreased in the apical region compared to the control (Figure 2A). In addition, the first root hair in 5.0 $\mu \mathrm{M}$ NCS treated roots was farther from the root tip than that in the control (Figure 2B). This suggests that the effects of NCS on cell differentiation in Arabidopsis roots are concentrationdependent.

When cells reach a predetermined size, cell fate (division, differentiation or other processes) is governed by various cell-cycle control proteins in concert with diverse signals [30]. To examine how NCS affects the process of cell division, two GUS fusion lines, $C D K A ; 1::$ uid $A$ and $C Y C B 1: 1::$ uid $A$, were used. The $C D K A: 1$ promoter activity reflects the state of competence for cell division [31,32] and is constitutively expressed throughout the cell cycle [11]. In contrast, the $C Y C B 1: 1$ promoter activity marks the progression from late $G 2$ to $M$ phase [33]. Whole-mount GUS assay samples were prepared from each line at day 2 or day 4 after transferring to the NCS-containing medium. The expression of $C D K A ; 1$ was inhibited after 4 days of 1.0 and $5.0 \mu \mathrm{M}$ NCS treatment (Figure 2C). The CYCB1:1 promoter activity was also inhibited (Figure 2D) after 

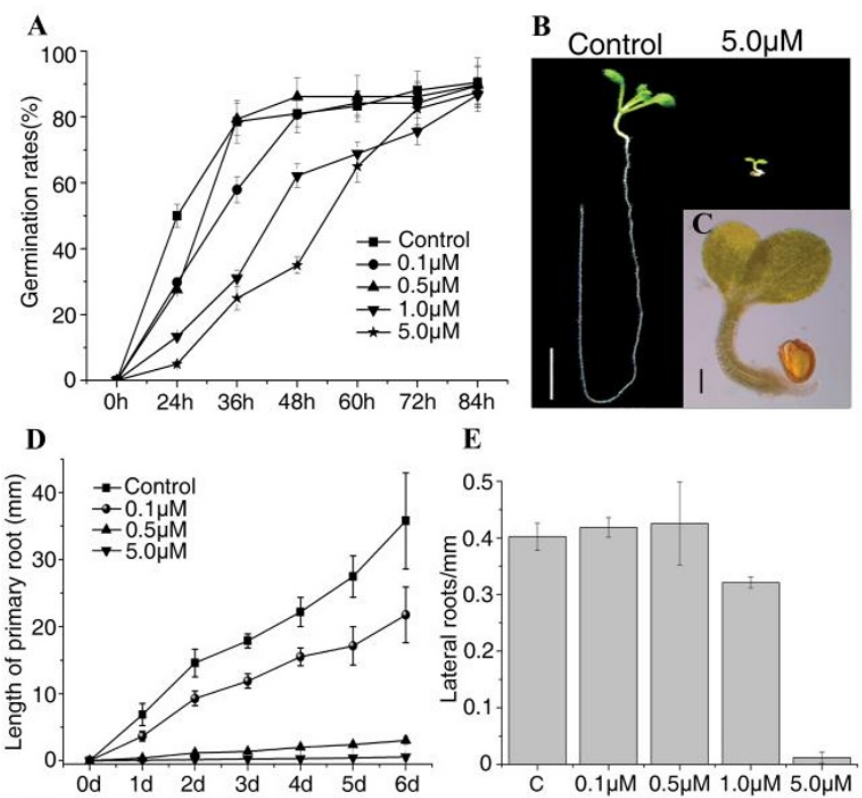

E

$\mathbf{F}$
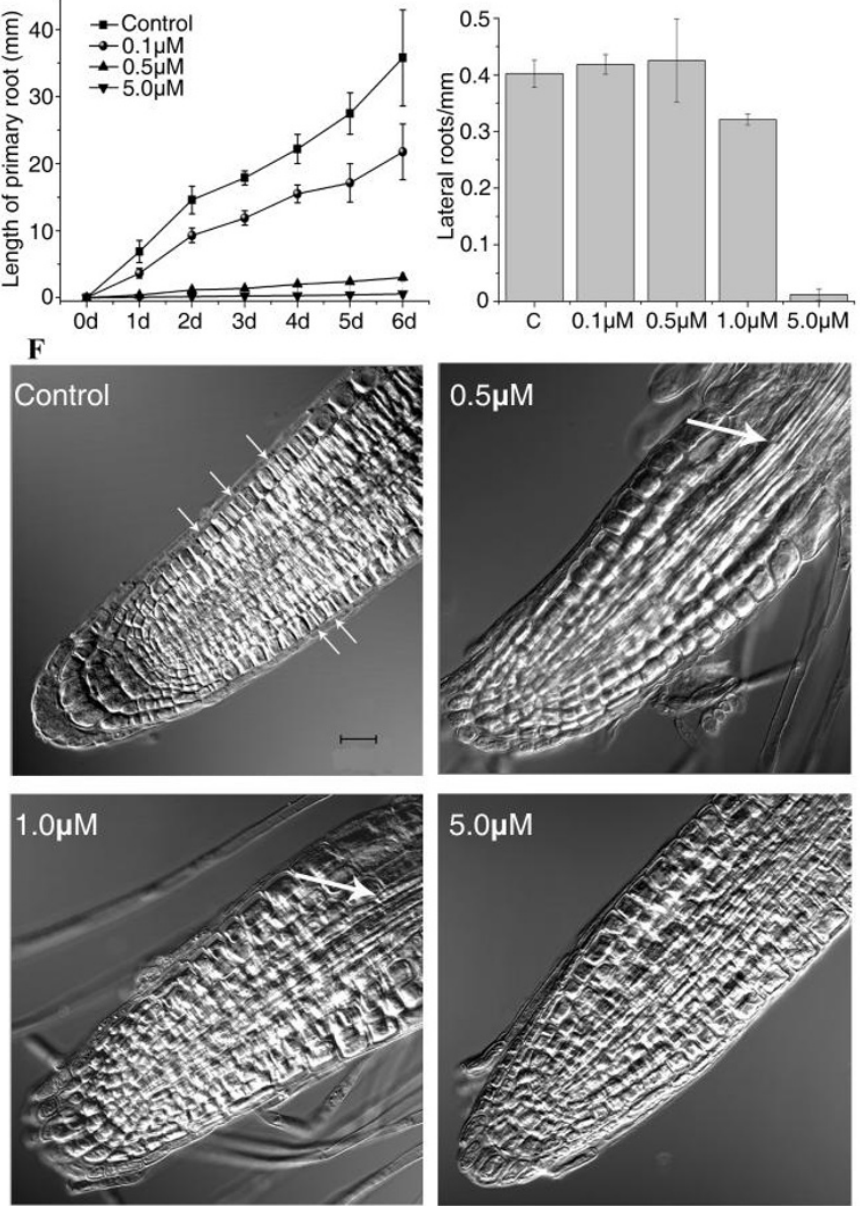

Figure 1 Effects of NCS on the post-embryonic development of Arabidopsis roots. (A) Inhibitory effect of NCS on radicle protrusion during seed germination. (B) Wild type Arabidopsis seedling at 10 days after stratification grown on medium containing 0 or $5.0 \mu \mathrm{M} \mathrm{NCS}$. Bar $=5 \mathrm{~mm}$. (C) A close-up view of the whole plant in (B) treated with $5.0 \mu \mathrm{M} \mathrm{NCS}$. Bar $=1 \mathrm{~mm}$. (D) NCS inhibits primary root elongation. Root growth time course was measured after transferring 3-day-old Arabidopsis seedlings to NCS-containing medium. (E) NCS affects the lateral root density after exposing to NCS for 7 days. Data shown in (A), (D), (E) are means \pm SD obtained from three independent experiments $(n \geqq 20, P<0.01)$. (F) Effects of NCS on cell expansion and cell division of meristematic cells. Arrows in the control panel showed the dividing cells. Bars $=50 \mu \mathrm{m}$ in all panels. Differential interference contrast (DIC) images were captured using the transmission light detector of the confocal microscope.

2 days of NCS treatment. These findings indicate that NCS can affect the expression of cell cycle genes in Arabidopsis roots.

We further investigated the expression of a quiescent center (QC) marker line, QC25. As shown in Additional file 1: Figure S3A, the expression of QC25 was not affected by NCS. When NCS-treated Arabidopsis seedlings were transferred to the NCS-free medium, the primary roots grew normally (Additional file 1: Figure S3B, $\mathrm{C}$ and D). Furthermore, NCS neither induced cell death 


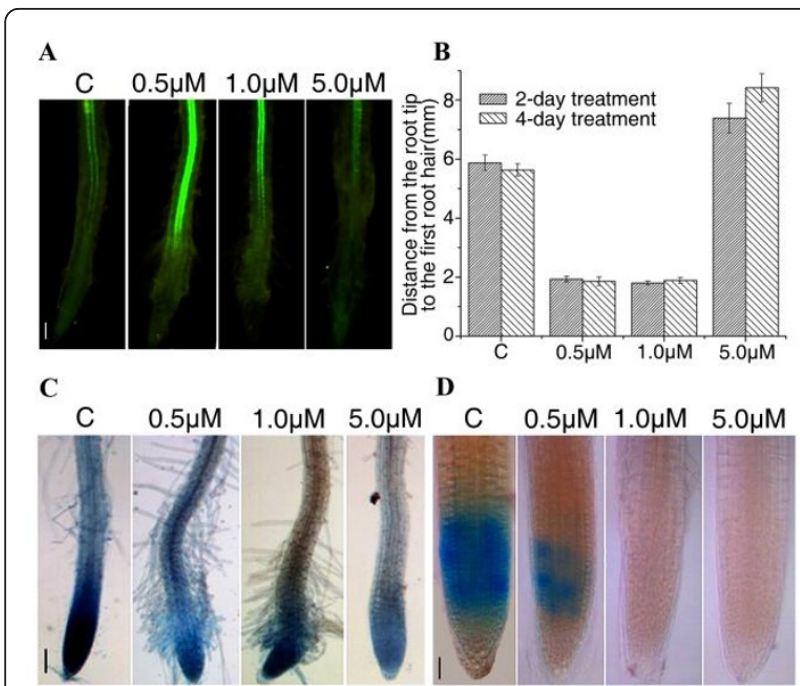

Figure 2 Effects of NCS on cell division and cell differentiation in Arabidopsis root tips. (A) NCS affects the differentiation of xylem pole pericycle cells in the root tip. Bar $=200 \mu \mathrm{m}$. (B) The development of root hairs in Arabidopsis primary roots was affected by NCS. Data

shown are means \pm SD obtained from three independent experiments ( $n \geqq 20$ ). (C) CDKA;7::uidA promoter activity after NCS treatment for

4 days. Bar $=200 \mu \mathrm{m}$. (D) Expression of the mitotic marker CYCB1; 1::uidA after 2 days NCS treatment. Bar $=50 \mu \mathrm{m}$.

(Additional file 1: Figure S4A) nor oxidative stress (Additional file 1: Figure S4B and C) in Arabidopsis roots, indicating that this substance did not exert toxic effects on Arabidopsis roots at concentrations used in this study.

Effects of NCS cannot be rescued by hormone treatment Phytohormones exert profound effects on plant growth and development. To investigate whether the inhibited Arabidopsis root growth is caused by lack of a hormone in the medium containing NCS, we supplemented the medium with a variety of phytohormones: NAA, IAA, 2,4-D, 6-BA, KIN and GA (each was applied at concentrations of $10^{-9}, 10^{-8}, 10^{-7}, 10^{-6}$ and $\left.10^{-5} \mathrm{M}\right)$. Results showed that none of these phytohormones were able to restore the root growth in either 0.5 or $5.0 \mu \mathrm{M}$ NCS treatments (Additional file 1: Table S2). Thus, we concluded that the inhibitory effects of NCS on Arabidopsis root growth were not caused by deficiency of any of these growth regulators.

\section{Effects of NCS on cell cycle progression}

To specifically study the effects of NCS on cell cycle progression, a suspension cell system that allows cell synchronization with inhibitors of cell cycle progression should be used. For this reason, we chose the highly specialized tobacco (Nicotiana tabacum) cell line (BY-2) that has been extensively used for cell cycle studies in plants [34].
First, whether NCS had similar inhibitory effects on tobacco root development as observed in Arabidopsis roots was determined by germinating tobacco seeds on a medium containing $0.5 \mu \mathrm{M}$ NCS. Similar to the observation in Arabidopsis plants, NCS significantly inhibited the primary root growth of tobacco seedlings (Figure 3A and $3 \mathrm{~B})$. Then, we examined whether NCS treatment affects cell division in BY-2 suspension cultured cells. Exponentially growing BY-2 cells were washed with medium lacking 2,4-D for three to five times, then equal amount of cells were diluted in different media. After two-day treatment, cells were photographed. As shown in Figure 3C, chains of small BY-2 cells were observed in the control medium. Although cell division was not completely inhibited, $0.5 \mu \mathrm{M}$ NCS-treated cells were bigger than that of the control (Figure 3C). When treated with 5.0 $\mu \mathrm{M}$ NCS, most BY-2 cells greatly expanded similar to auxin-starved cells (Figure 3C). The effect of NCS treatment on cell cycle progression in highly synchronized BY-2 cells was further validated using flow cytometric analysis. BY-2 cells were treated with different concentrations of NCS after depletion of aphidicolin (see methods below). There was no difference between control and NCS-treated cells in $3 \mathrm{~h}$, suggesting that NCS did not affect cells entry into $S$ phase after depletion of aphidicolin (Figure 3D). Six hours after depletion of aphidicolin, $35.6 \%$ of control cells were at G2 phase, whereas only $7.3 \%$ of $0.5 \mu \mathrm{M}$ NCS-treated cells and $0.7 \%$ of $5.0 \mu \mathrm{M}$ NCS-treated cells were at G2 phase. After $0.5 \mu \mathrm{M}$ NCS treatment for $12 \mathrm{~h}$, a pronounced increase of the nuclear population at S phase was observed (Figure 3D). The population of $S$ phase nuclei remained at about $35.2 \%$ after $5.0 \mu \mathrm{M}$ NCS treatment for $3 \mathrm{~h}$, and did not change up to $12 \mathrm{~h}$ (Figure 3D). The almost complete depletion of the $\mathrm{G} 2$ population after $5.0 \mu \mathrm{M}$ NCS treatment indicated that few cells could pass $S$ phase to G2 phase under this condition. To study the underlying mechanism of cell cycle blocking induced by NCS treatment, the expression of four tobacco cell cycle genes, CYCD3:1, Histone H4, CYCA1:1 and $C Y C B 1: 1$ was investigated by quantitative reverse transcription PCR (qRT-PCR). Results in Figure 3Eshowed that in untreated synchronized cells, CYCD3:1 mRNA accumulated at the early G1 phase at $0 \mathrm{~h}$ and down-regulated during progression through the $S$ phase; Histone $H 4$ mRNA accumulated at the G1-to-S phase transition from 0 to $1 \mathrm{~h}$, whereas CYCA1:1 mRNA started to accumulate at mid-S phase from 3 to $6 \mathrm{~h}$. The expression of $C Y C B 1: 1$ increased at G2-to-M phase from 6 to $8 \mathrm{~h}$. The expression pattern of these four cyclin genes was similar to that previously observed [35], confirming the marker role of each gene in the cell cycle transition. Interestingly, the temporal expression pattern of cell cycle genes described above was altered by NCS treatment. 0.5 $\mu \mathrm{M}$ NCS increased the expression levels of 

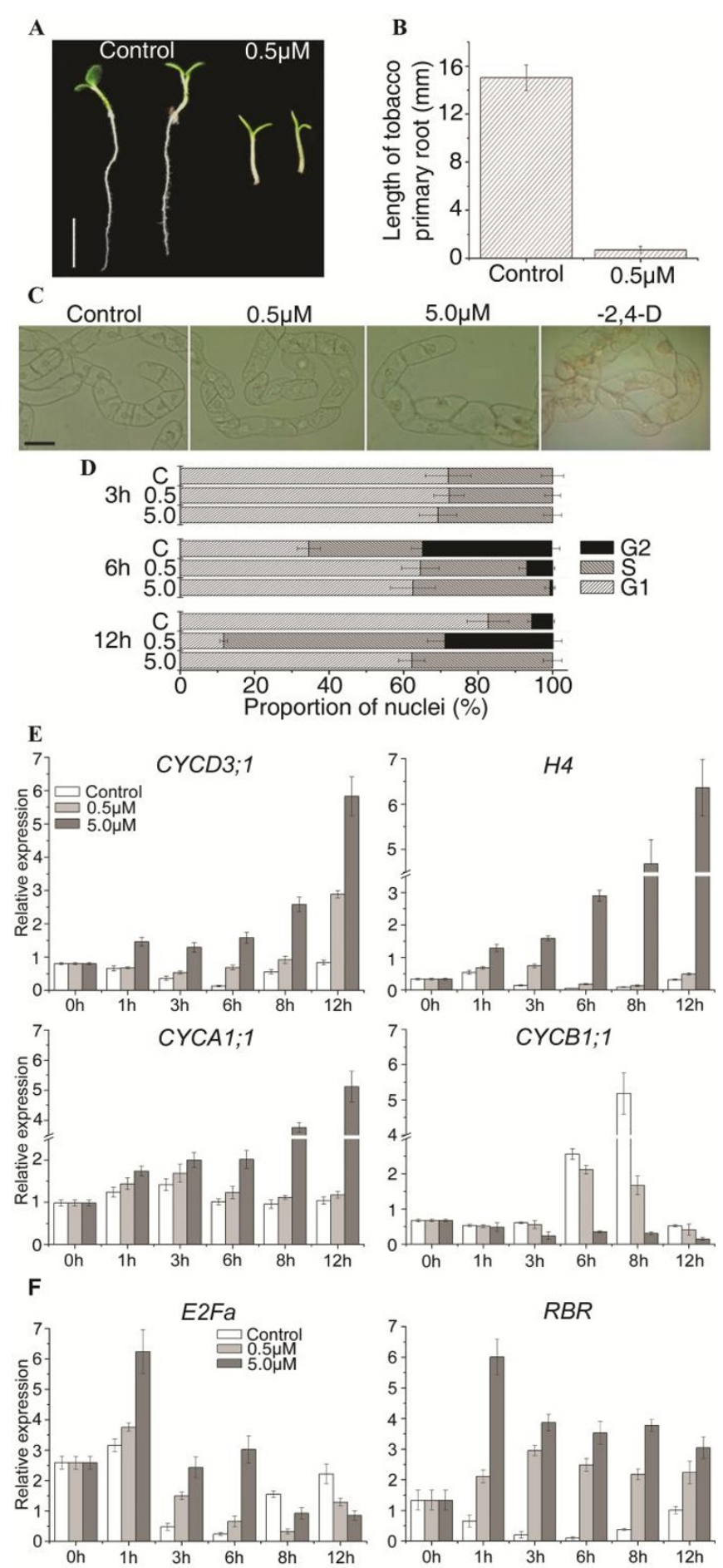

Figure 3 Using a tobacco cell suspension to determine the effects of NCS on cell cycle. (A) The phenotype of 7 days after germination (DAG) tobacco seedlings grown on $0.5 \mu \mathrm{M} \mathrm{NCS}$. Bar $=5 \mathrm{~mm}$. (B) Primary root length of 7 DAG tobacco seedlings was inhibited by NCS. Values are means \pm SD of three independent experiments $(n \geqq 20)$. (C) Images of BY-2 cells treated with NCS and depletion of 2,4-D for 2 days. Bar $=$ $50 \mu \mathrm{m}$. (D) Flow cytometric analysis of the cell cycle. (E) qRT-PCR detection of CYCD3;1, Histone H4, CYCA1;1 and CYCB1;1 mRNA after NCStreatment in synchronized tobacco BY-2 cells. (F) E2Fa and RBR transcription level in BY-2 cells after NCS-treatment. The relative expression is normalized to ACTIN2. Data shown were the means \pm S.D of three independent experiments. 
CYCD3:1, Histone H4, and CYCA1:1 at specific phases but delayed the timing of expression (Figure $3 \mathrm{E}$ ). For CYCB1:1, $0.5 \mu \mathrm{M}$ NCS markedly modified the amplitude at $8 \mathrm{~h}$. However, $5.0 \mu \mathrm{M}$ NCS greatly stimulated the expression of CYCD3:1, Histone H4 and CYCA1:1, and disturbed the pattern of expression compared to the control. The expression of $C Y C B 1: 1$ was greatly inhibited by $5.0 \mu \mathrm{M}$ NCS. These results showed that the expression of cell cycle genes in BY-2 cells was disturbed by NCS. To further investigate the effects of NCS on the cell cycle gene expression and DNA replication, we examined the mRNA levels of $E 2 F a$ and $R B R$ in synchronized BY-2 cells. The $E 2 F a$ transcripts were up-regulated from 1 to 6 $\mathrm{h}$, and down-regulated from 8 to $12 \mathrm{~h}$ of NCS treatment (Figure 3F). With the NCS treatment for 1-12 h, RBR transcripts were significantly stimulated (Figure 3F), confirming that the transcription activity of E2Fa/DPa on the gene transcription and entry into $S$ phase may be repressed by NCS through up-regulation of $R B R$ expression.

\section{NCS affects the expression of core cell cycle genes in Arabidopsis root tips}

To further validate our studies on the expression of cell cycle genes in BY-2 cells, we analyzed the effects of NCS on mRNA levels of key cell cycle genes in root tips of Arabidopsis seedlings by qRT-PCR. Plants were sampled at eight time points during treatment to check the expression of CDKA;1,CYCD3:1, CYCD3:2, E2Fa, CDKB1:1 and $C D K B 2: 1$ (Figure 4A). $C D K A ; 1$ transcript was inhibited by NCS after $6 \mathrm{~h}$ treatment. Expression of CYCD3:1 was increased sharply from $9 \mathrm{~h}$ of $0.5 \mu \mathrm{M}$ NCS treatment. $C Y C D 3: 2$ showed a very similar expression pattern as $C Y C D 3: 1$ in $0.5 \mu \mathrm{M}$ NSC treatment. However, unlike CYCD3:1, an increase in CYCD3:2 expression was also observed in $5.0 \mu \mathrm{M}$ NCS treatment. As shown in Figure 4A, 0.5 and $5.0 \mu \mathrm{M}$ NCS enhanced $E 2 F a$ mRNA accumulation. The expression of $C D K B 2: 1$ increased about two fold at 12 and $24 \mathrm{~h}$, and then decreased to the control level at $48 \mathrm{~h}$ in $0.5 \mu \mathrm{M}$ NCS treatment, whereas in $5.0 \mu \mathrm{M}$ NCS treatment, the expression was inhibited after $6 \mathrm{~h}$. $C D K B 1: 1$ transcript levels steadily decreased in plants treated with NCS (Figure 4A). These results indicated that the expression of G1/S and G2/M phase gene in Arabidopsis root tips was disturbed by NCS. This perturbation may affect the cell differentiation in Arabidopsis root tips.

Previous studies suggest that cell division and differentiation are accompanied by full genome duplication [36]. In this study, we showed that 0.5 and $1.0 \mu \mathrm{M}$ NCS treatment stimulated cell differentiation in Arabidopsis roots (Figure 1F, 2B and 2C). The differentiation of pericycle cells and root hairs was inhibited by $5.0 \mu \mathrm{M}$ NCS, although the expression of $C Y C D 3: 2$ was increased. In order to test whether the effects of $5.0 \mu \mathrm{M}$ NCS on cell differentiation were caused by inhibition of DNA replication, we further analyzed two putative E2F targets, CDC6a and DNA polymerase $\alpha$, which contain E2F sites in their promoters and participate in the initiation of DNA replication [37]. The result showed that DNA polymerase $\alpha$ exhibited a similar changing pattern as $C D K B 2: 1$, i.e. the $D N A$ polymerase $\alpha$ transcription was stimulated by 0.5 $\mu \mathrm{M}$ NCS at $12 \mathrm{~h}$, but inhibited at $48 \mathrm{~h}$, and was dramatically decreased by $5.0 \mu \mathrm{M}$ NCS treatment (Figure 4B). CDC6 a mRNA was greatly decreased by $5.0 \mu \mathrm{M}$ NCS, but was only slightly inhibited by $0.5 \mu \mathrm{M}$ NCS treatment before $12 \mathrm{~h}$ (Figure 4B). This means that the E2Fa/DPa activity was not affected by $0.5 \mu \mathrm{M}$ NCS before $12 \mathrm{~h}$. Down-regulation of these two genes by $5.0 \mu \mathrm{M}$ NCS affects the formation of origin recognition complex (ORC), and then disturbs the activation of DNA replication origins. This finding indicates that NCS may affect the transcription activity of E2Fa/DPa in a concentrationdependent manner.

\section{Reduction of CDK activity in NCS-treated Arabidopsis roots}

As previously reported, the CDKA activity determines whether a cell undergoes division or differentiation $[13,38]$. To analyze the effects of NCS on CDKs, we examined the expression of two CDK inhibitors, KRP1 and $K R P 2$, by qRT-PCR. KRP1 mRNA was mildly upregulated by $0.5 \mu \mathrm{M}$ NCS. In contrast, it was strongly stimulated in $5.0 \mu \mathrm{M}$ NCS-treated roots (Figure 5A). The KRP2 expression pattern in NCS-treated roots was different from that of KRP1. The expression of KRP2 was not affected by NCS before $24 \mathrm{~h}$, but was stimulated at $48 \mathrm{~h}$ of NCS treatment (Figure 5A).

KRP1 and KRP2 protein abundance is regulated posttranscriptionally through CDK phosphorylation and proteasomal degradation [39]. Therefore, we checked the KRP2 protein abundance by immunoblot analysis. Differences of KRP2 protein abundance between roots treated with 0.5 and $5.0 \mu \mathrm{M} \mathrm{NCS}$ were observed (Figure $5 \mathrm{~B}$ ). The level of KRP2 in $0.5 \mu \mathrm{M}$ NCS-treated roots was elevated at $48 \mathrm{~h}$. In $5.0 \mu \mathrm{M}$ NCS-treated roots, KRP2 accumulated after $6 \mathrm{~h}$ of treatment and was higher at $6,12,24$ and $48 \mathrm{~h}$ than that in $0.5 \mu \mathrm{M}$ NCS-treated roots (Figure $5 \mathrm{~B}$ ).

To further determine whether upregulation of these two inhibitors affects the CDK activity, we measured the p10CKS1At-bound CDK activity in Arabidopsis roots. The CDK activity was slightly inhibited by NCS before $12 \mathrm{~h}$, but it decreased to $45.5 \%$ of the control in $0.5 \mu \mathrm{M} \mathrm{NCS}$ treatment for $48 \mathrm{~h}$ and to $33.2 \%$ and $10.1 \%$ in $5.0 \mu \mathrm{M}$ NCS treatment for 24 and $48 \mathrm{~h}$, respectively (Figure $5 \mathrm{C}$ and $5 \mathrm{D})$. The CDK activity was more severely inhibited at 24 and $48 \mathrm{~h}$ in $5.0 \mu \mathrm{M}$ NCS-treated roots than in roots treated with $0.5 \mu \mathrm{M}$ NCS (Figure $5 \mathrm{C}$ and $5 \mathrm{D}$ ). It has been postulated that $\mathrm{CDKB} 1 ; 1$ regulates the $\mathrm{CDKA} ; 1$ activity in 

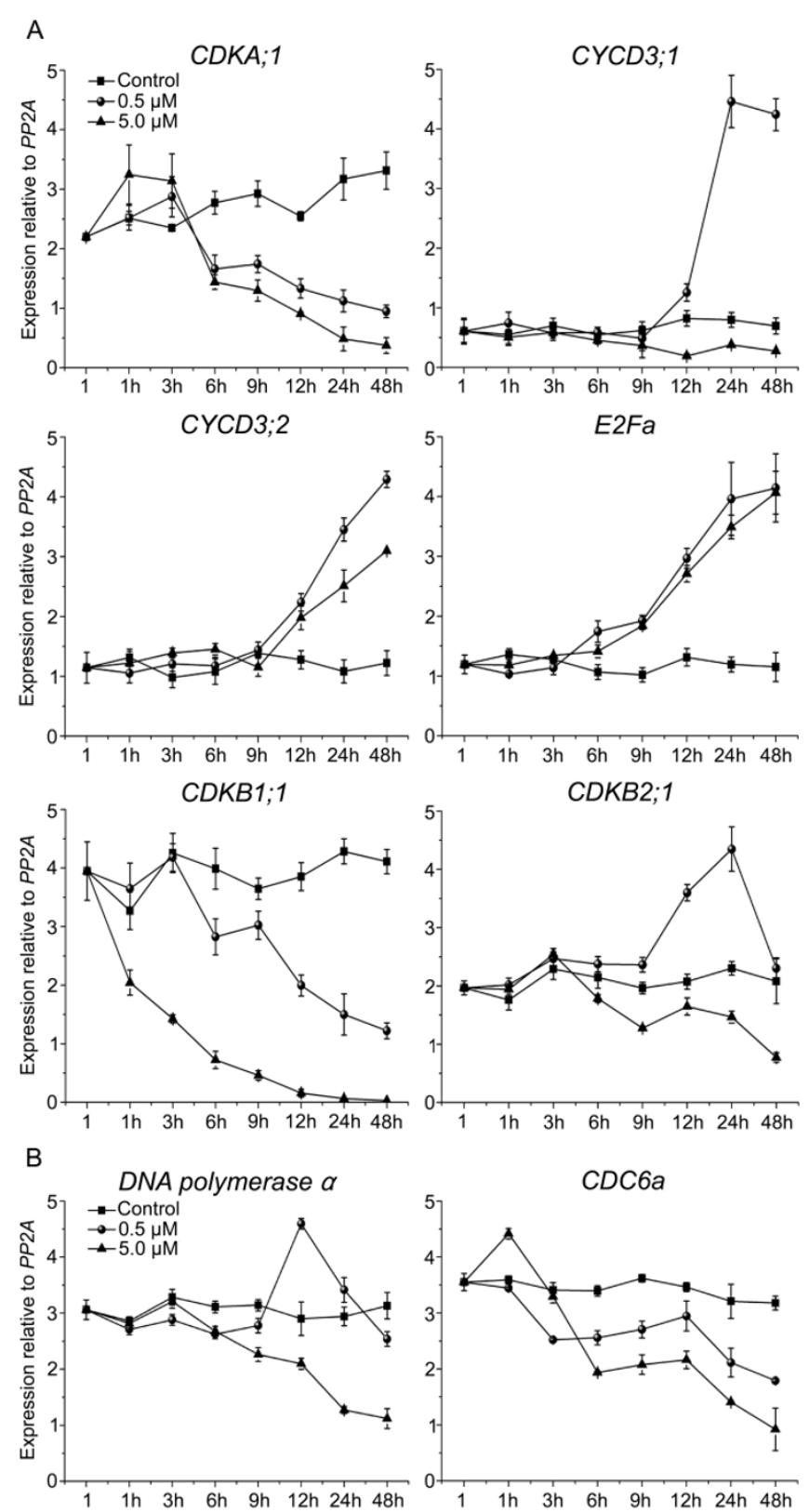

Figure 4 qRT-PCR analysis of the expression of core cell cycle genes in Arabidopsis root tips. (A) qRT-PCR results showing the effects of NCS on expression of CDKA;1, CYCD3;1, CYCD3;2, E2Fa, CDKB1;1 and CDKB2;1 in Arabidopsis root tips. (B) The relative expression (normalized to PP2A) of DNA polymerase $\alpha$ and CDC6a after NCS treatment for indicated times. Data shown in (A) and (B) are means \pm SD of three independent experiments,

dividing cells through controlling the KRP2 protein abundance [39]. If so, the accumulation of KRP2 protein and the inhibition of the CDK activity observed following NCS treatment may be caused by the inhibition of $C D K B 1 ; 1$ expression. Together with the data on cell differentiation and expression of E2Fa downstream genes in Arabidopsis root tips, these results indicate that $\mathrm{CDK} /$ cyclin complexes with roles in both cell division and differentiation are impaired by $5.0 \mu \mathrm{M}$ NCS treatment, whereas the mitotic CDK complexes are mainly targeted by NCS at $0.5 \mu \mathrm{M}$.

\section{Discussion}

NCS inhibits cell proliferation in the root apical meristem Germination entails the resumption of growth and development by a complex series of processes and is generally considered to be complete when the radicle penetrates 


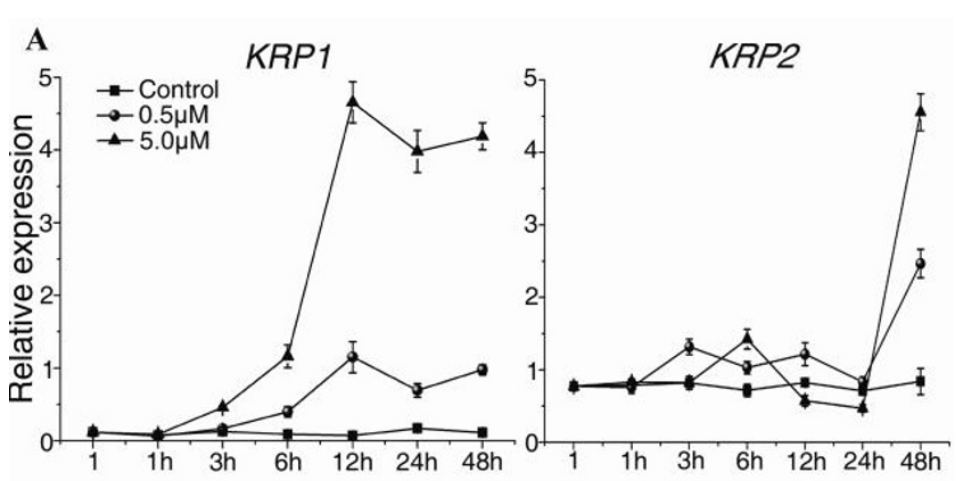

B

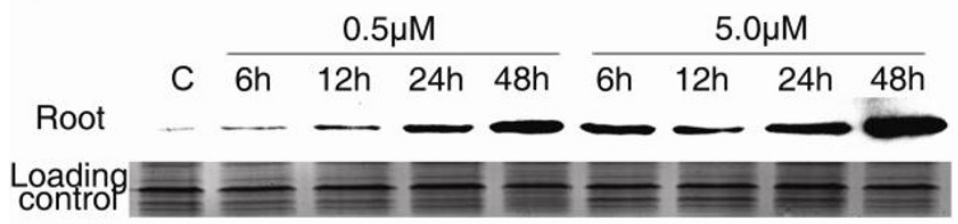

C

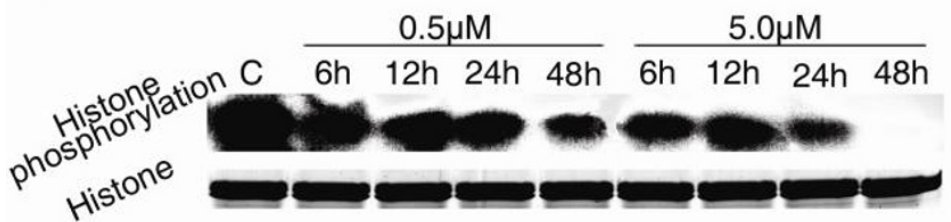

D

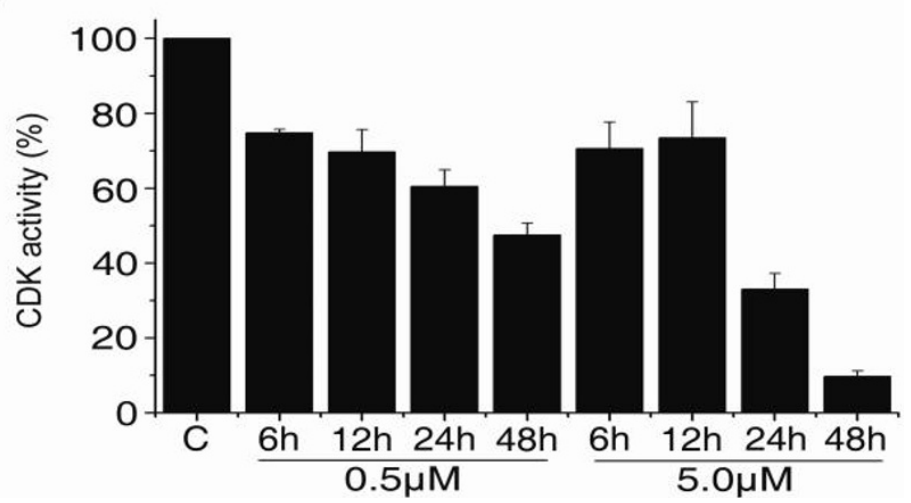

Figure 5 Analysis of KRP1 and 2 expression and CDK activity after NCS treatment. (A) qRT-PCR analysis of KRP1 and KRP2 expression relative to PP2A. (B) Immunoblot analysis of NCS-treated Arabidopsis roots using an anti-KRP2 antibody. Coomassie Brilliant Blue staining of the electrophoresis gel was used as a loading control. (C) P10 CKS1At-associated kinase activity in NCS-treated roots. Autoradiogram showing typical results of CDK activity assays with histone as the substrate. Coomassie Brilliant Blue staining of the electrophoresis gel with histone was used as a control for equal substrate quantity per phosphorylation reaction. (D) Relative quantification of three independent kinase activity measurements as depicted in (C). The control was arbitrarily set at 100\%. Data shown in (A) and (D) are means \pm SD of three independent experiments.

the seed coat [40]. In the germination process, exit from G1 phase, entry into $\mathrm{S}$ phase, and cell division in a subset of cells in the root meristem precedes radicle protrusion in Arabidopsis [41]. In the present study, we found that NCS significantly delayed radicle emergence (Figure 1A). Similar effects of aphidicolin and roscovitine were observed in previous research. As a DNA polymerase and
CDK inhibitor, respectively, aphidicolin and roscovitine significantly delay radicle protrusion, indicating that both DNA synthesis and CDK activity contribute to the elongation of the radicle during its emergence [41]. These findings suggest that cell division is important for radical emergence. Our data also showed that cell division (Figure 1F), mitotic index (Additional file 1: Figure S1B) 
and the expression of $\mathrm{G} 2 / \mathrm{M}$ phase cell cycle genes in Arabidopsis roots were inhibited by NCS (Figure 2D and 4A). The p $10^{\text {CKS1At }}$-bound CDK activity in Arabidopsis roots was reduced by NCS (Figure $5 \mathrm{C}$ and $5 \mathrm{D}$ ). All these results strongly suggest that the effects of NCS on the post-embryonic development of Arabidopsis roots are correlated with reduced numbers of dividing cells in the radicle meristem zone.

\section{NCS modulates the expression of cell cycle genes}

Cell cycle regulation is of pivotal importance for plant growth and development. Studies have shown that a key element of the cell cycle progression control in plants is the regulation of cell cycle genes $[5-7,42]$. For example, Dewitte et al. found that constitutive over-expression of CYCD3:1 increased the CYCD3:1-associated kinase activity, reduced the proportion of cells in the G1 phase of the cell cycle, and caused marked developmental changes [7]. In addition, ectopic expression of $E 2 F a$ induced sustained cell proliferation in normally-differentiated cotyledons and hypocotyls [43]. Boudolf et al. found that the expression of a dominant-negative allele of the Arabidopsis $C D K B 1: 1$ gene inhibited cell division and enhanced endo-reduplication [44]. In the present study, the expression of some cell cycle genes in both BY-2 cells (Figure $3 \mathrm{E}$ and $3 \mathrm{~F}$ ) and Arabidopsis root tips (Figure 4A) was affected by NCS. In general, the expression of $\mathrm{G} 1 / \mathrm{S}$ phase genes was stimulated but the expression of G2/M phase genes was reduced by NCS treatment. For some cell cycle genes, such as CYCD3;1, the effect of NCS on its expression is concentration-dependent in Arabidopsis root tips (Figure 4A). There are also some discrepancies in the effects of NCS on cell cycle genes in synchronized BY-2 cells and Arabidopsis root tips. For example, the mRNA level of CYCD3;1 was differently affected by $5 \mu \mathrm{M}$ NCS (Figure 3E and 4A). This may be caused by the differences between the two plant cell systems. Previous results also showed that the expression of D-type cyclins in BY-2 cell cultures is different from that in Arabidopsis cell cultures (6).

We further found that NCS stimulated the transcript accumulation of KRP1, and the KRP2 protein abundance in Arabidopsis roots (Figure 5A and 5B). With the function of these two inhibitors, the CDK activity was affected differently by NCS depending on concentrations. The decreased CDK activity affected the transcriptional activity of E2Fa/DPa (Figure 4B). This also explains why the expression of DNA polymerase $\alpha$ was up-regulated by $0.5 \mu \mathrm{M} \mathrm{NCS}$ at $12 \mathrm{~h}$. The transcriptional activity of E2Fa/ DPa may not be inhibited by $0.5 \mu \mathrm{M}$ NCS at $12 \mathrm{~h}$ because the CDK activity was not low enough (Figure 5C and 5D). The disturbance of expression of G1/S and G2/M phase cell cycle genes by NCS significantly affected the postembryonic development of the Arabidopsis roots.

\section{NCS shows different roles in cell differentiation through} KRPs in a concentration-dependent manner

As proven in other eukaryotic organisms, cyclin-dependent kinases (CDKs) govern the cell cycle in plants. Different CDK-cyclin complexes phosphorylate a plethora of substrates at the key G1-to-S and G2-to-M transition points, triggering the onset of DNA replication and mitosis, respectively. In plants, a bona fide PSTAIRE CDK, designated CDKA, plays a pivotal role at both the G1-to-S and G2-to-M transition points. Overproduction of a dominant negative CDKA of Arabidopsis thaliana in tobacco plants yields smaller plants. However, the G1/G2 ratio remains unaltered, corresponding with the observation that the CDKA activity can be detected at both checkpoints [45-47]. Thus, CDKA is essential at both G1-to-S and G2-to-M transitions of the cell cycle. Plants also possess a unique class of CDKs, the so called B-type CDKs that have not been described in any other organisms [48-50]. In B-type CDKs the PSTAIRE hallmark presented in CDKAs is replaced by either PPTALRE or PPTTLRE, reflecting the existence of two subgroups, CDKB1 and CDKB2 [14]. The requirement of CDKB1 activity to progress through mitosis has been demonstrated with a dominant negative approach, illustrating that a reduction in the CDKB1 activity results in an increased $4 \mathrm{C} / 2 \mathrm{C}$ ratio because of a block at the G2-to-M transition [47,51]. Our results showed that the CDK activity was differently affected by NCS in Arabidopsis roots (Figure 5C and 5D). Although the p10 ${ }^{\mathrm{CKS} 1 \mathrm{At}}$-bound CDKs probably contain both A-type and B-type CDKs, the decreased CDK activity at 6 and $12 \mathrm{~h}$ inhibited cell division (Figure 1F and Additional file 1: Figure S1). It means that the G2/M transition needs a higher CDK activity than the G1/S transition. Previous study showed that in Drosophila a special CDK inhibitor, ROUGHEX (RUX), binds to and inactivates mitotic CDK complexes, helping to establish a G1-phase with low CDK activity [52,53]. In addition, onset of $S$ phase requires a lower threshold of protein kinase activity than onset of mitosis, ensuring that a G1 cell would automatically initiate $S$ phase before mitosis [54]. From this viewpoint, the role of 0.5 or $1.0 \mu \mathrm{M}$ NCS on cell differentiation could be an indirect effect, whereby the inhibitory effects of low concentrations of NCS on cell cycle in mitotically dividing cells may trigger the initiation of cell differentiation in the Arabidopsis root tips.

In several mis-expression studies, KRPs block endoreplication and reduce cell numbers, leading to dwarfed plants in extreme cases $[13,17,18,39,55,56]$. We observed similar phenomena in Arabidopsis roots, since the expression of KRP1 and the abundance of KRP2 protein were enhanced by NCS (Figure 5A and 5B). However, the KRP2 transcript was not stimulated by NCS before $24 \mathrm{~h}$. It means that the KRP1 expression is more sensitive to NCS than that of KRP2, and that the inhibitory 
effects of NCS at the first few hours may be caused by the upregulation of KRP1. From this point of view, stimulation of KRP1 may be the reason why NCS inhibits cell division at the first few hours. To verify this, we checked the KRP2 protein abundance after NCS treatment (Figure $5 \mathrm{~B}$ ). The result indicated that upregulation of KRP1 caused the accumulation of KRP2 protein by its role on the CDK activity before $24 \mathrm{~h}$. Previous results of mis-expression of KRP1 observed by Weinl et al. suggested that KRP1 acts in a concentration-dependent manner, blocking the G1/S transition at high concentrations, and the G2/M transition at low concentrations [56]. In addition, Verkest et al. reported that KRP2 gainof-function has either a positive or negative effect on plants' DNA ploidy levels, depending on the level of KRP2 over-expression [39]. Our results showed that 0.5 $\mu \mathrm{M}$ NCS mildly upregulated KRP1 (Figure 5A) and KRP2 (Figure $5 \mathrm{~B}$ ), thus causing prematuration in the meristematic zone (Figure 1F, Additional file 1: Figure S2 and Figure 2A). In contrast, $5.0 \mu \mathrm{M}$ NCS significantly stimulated the KRP1 expression (Figure 5A) and KRP2 protein abundance (Figure $5 \mathrm{~B}$ ), seriously inhibiting the CDK activity which is required for the progression of G1/S phase at 24 and $48 \mathrm{~h}$ (Figure 5C and 5D), and then inhibited cell differentiation in Arabidopsis root tips.

In higher plants, where organogenesis occurs continuously, most cells maintain their ability to re-enter and regulate the cell cycle in response to molecular signals, such as auxin. Previous report showed that the expression of KRP1 and KRP2 is high in the inactive pericycle cells of NPA-treated roots [32]. Our recent results showed that polar auxin transport in Arabidopsis roots was inhibited by NCS [57]. It means that the effects of NCS on cell cycle progression may be caused by its role on auxin transport. We also showed that exogenous plant hormones cannot restore the inhibitory effects of NCS on root development (Additional file 1: Table S2), which is different from that of NPA, a general auxin polar transport blocker [58]. The treatment with exogenous hormones may not rescue the state of hormone distribution and/or signaling in NCS treated roots. The effects of NCS on the development of root hairs may be also caused by its role on auxin signaling, because previous research confirmed that auxin participates in the differentiation of root hairs [59]. However, how NCS affects auxin signaling in Arabidopsis roots remains to be elucidated.

\section{Conclusions}

Taken together with earlier findings, our results indicate that at low concentration NCS preferentially inhibits mitotic cell cycle specific/cyclin complexes, whereas at high concentration the strong accumulation of KRP1 and KRP2 protein affects the $\mathrm{CDK} /$ cyclin complexes with consequent effects at both G1/S and G2/M phases. Thus, the inhibition effects of low concentration of NCS on cell cycle in mitotically dividing cells may trigger the initiation of cell differentiation in Arabidopsis root tips. This disturbance of the balance of G1/S and G2/M phase cell cycle genes by NCS significantly affected the post-embryonic development of the Arabidopsis roots. Identifying the molecular targets in the plant cell of this natural compound may provide new insights about the regulatory pathways involved in cell cycle control and cell differentiation in the root meristem.

\section{Methods}

\section{Purification of NCS}

NCS was isolated and purified from $N$. tazetta bulbs according to Bi et al. [27].

\section{Plant materials and culture conditions}

The Arabidopsis Columbia ecotype (Col-0), and the transgenic lines CYCB1:1::uidA, CDKA;1::uidA (C24), QC25::uidA, and J0121 were used in this study. Initially, the effects of NCS on the germination rate of WT Arabidopsis seeds and the root growth of resulting seedlings were examined by surface-sterilizing seeds and placing them on plates of $1 / 2 \times$ MS medium ( $\mathrm{pH}$ 5.7) containing $1.0 \%(\mathrm{w} / \mathrm{v})$ sucrose, $1.0 \%(\mathrm{w} / \mathrm{v})$ agar and NCS at concentrations of $0.1,0.5,1.0$ or $5.0 \mu \mathrm{M}$. The plates were kept at $4^{\circ} \mathrm{C}$ for 4 days before transferring to a growth chamber, where they were placed in racks at an angle of ca. $85^{\circ}$ relative to horizon. The plates were maintained at $21 \sim 23^{\circ} \mathrm{C}$ under a $16 / 8 \mathrm{~h}$ photoperiod for $84 \mathrm{~h}$, during which they were continuously observed and their germination rates and timing of radical emergence were recorded. After transferring the three-dayold seedlings to NCS for 7 days, the seedlings were photographed and the length of their primary roots was measured from digital images of the plates using Image J software (NIH, version 1.62), while lateral roots and lateral root primordia were counted under a dissecting microscope.

\section{Tobacco BY-2 cell suspension and synchronization}

Tobacco Bright Yellow 2 (BY-2) cell cultures were maintained as described [34]. For experiments with exponentially growing BY-2 cells, 3-day-old suspensions were used. For experiments with synchronized cells, synchronization was carried out as described by Reichheld. Briefly, sequential treatment with $3 \mu \mathrm{g} \mathrm{ml}^{-1}$ aphidicolin (Sigma, USA) for $24 \mathrm{~h}$ was used to specifically study the G1-to-S phase transition [35]. For the treatment with NCS at the G1-to-S phase transition, NCS was added at the indicated concentrations $1 \mathrm{~h}$ after the removal of aphidicolin. The time point of adding NCS was designated time 0 of the experiment. 


\section{Flow cytometry}

For flow cytometric analysis, protoplasts of tobacco BY-2 cells were prepared by incubating cells for $1 \mathrm{~h}$ with 1.5\% Cellulase R-10 (Yakult Company, Japan) and 0.1\% Mcerozyme R-10 (Yakult Company, Japan). The cells were incubated at $27^{\circ} \mathrm{C}$, washed, and lysed in Galbraith's buffer [60], filtered in 1\% formaldehyde through $10 \mu \mathrm{m}$ nylon mesh, treated with RNase A, and stained with propidium iodide $\left(50 \mu \mathrm{g} \mathrm{ml}^{-1}\right)$. Cytometric analysis was performed using at least $10^{4}$ nuclei on an EPICS flow cytometer (Beckman Coulter, USA). For all results presented in the text, two populations were considered as significantly different if their deviation exceeded $5 \%$.

\section{Confocal microscopy}

Confocal images were captured with a LSM510 Laser Confocal Scanning Microscope (Zeiss, Jena, Germany) using argon laser excitation at $488 \mathrm{~nm}$ and a 505-550 $\mathrm{nm}$ emission filter set for GFP fluorescence observation.

\section{Histochemical analyses}

Histochemical assays of the GUS activity were performed as described by Jefferson et al. with minor modifications [61]. Three-day-old CYCB1:1::uidA, CDKA;1::uidA or QC25 seedlings were treated with NCS (at concentrations and for times indicated in the text and the figures), then submerged in GUS staining buffer containing $1 \mathrm{mM} \mathrm{X-}$ Gluc, $100 \mathrm{mM}$ sodium phosphate (pH7.5), $0.5 \mathrm{mM}$ potassium ferricyanide, $0.5 \mathrm{mM}$ potassium ferrocyanide, $10 \mathrm{mM}$ EDTA and 0.1\% Triton X-100. Tissues were incubated at $37^{\circ} \mathrm{C}$ for $12 \mathrm{~h}$ and then fixed in $70 \%(\mathrm{v} / \mathrm{v})$ ethanol. Starch granules were stained as described by Willemsen et al. [62]. Samples were mounted in 30\% glycerol and photographed under a dissecting microscope.

\section{Quantitative reverse transcription PCR analysis}

Total RNA was extracted with Trizol (Invitrogen) from $100 \mathrm{mg}$ samples of cells of the tobacco line BY-2, or from ca. $5 \mathrm{~mm}$ samples of excised root segments and root tips of 6-day-old WT Arabidopsis seedlings. Before PCR analysis, total RNA was pretreated with RNase-free DNase (Promega, USA) to eliminate any contaminating genomic DNA. First-strand cDNA was synthesized from 1 to $2 \mu \mathrm{g}$ portions of total RNA using Superscript II reverse transcriptase (Invitrogen, USA). PCR reactions of $20 \mu \mathrm{l}$ were prepared using the Takara SYBR Premix ExTaq, with $2 \mu \mathrm{l}$ of template DNA. Real-time thermo cycling was performed using a ROTOR-GENE 3000 instrument (Corbett, Australia) with the following standard cycling conditions: $95^{\circ} \mathrm{C}$ for $10 \mathrm{~s}$, followed by 40 cycles of $95^{\circ} \mathrm{C}$ for $5 \mathrm{~s}$ and $60^{\circ} \mathrm{C}$ for $30 \mathrm{~s}$. The results were analyzed by Rotor-Gene Real-Time Analysis Software 6.1 (Build 81). The specific primers for each gene are shown in Additional file 1: Table S1.

\section{Protein extraction and immunoblotting}

Roots of 6-day-old Arabidopsis plants were harvested and used immediately, or frozen in liquid nitrogen and stored at $-70^{\circ} \mathrm{C}$. Proteins were extracted by grinding tissues with quartz sand in homogenization buffer $(50 \mathrm{mM}$ Tris, $\mathrm{pH}$ 7.2, $60 \mathrm{mM} \beta$-glycerophosphate, $15 \mathrm{mM}$ nitrophenyl phosphate, $15 \mathrm{mM}$ EGTA, $15 \mathrm{mM} \mathrm{MgCl} 2,2 \mathrm{mM}$ dithithreitol, $0.1 \mathrm{mM}$ vanadate, $50 \mathrm{mM} \mathrm{NaF}, 20 \mu \mathrm{g} \mathrm{ml}^{-1}$ leupetin, $20 \mu \mathrm{g} \mathrm{ml}^{-1}$ aprotein, $100 \mu \mathrm{M}$ benzamidine, $1 \mathrm{mM}$ phenylmethylsulfonyl fluoride, and $0.1 \%$ Triton $\mathrm{X}-100$ ). Following centrifugation at $10,000 \mathrm{~g}$ for $30 \mathrm{~min}$, proteins in the supernatant were separated by $11.5 \%$ SDS-PAGE and blotted onto Immobilon-P membranes (Millipore, USA). Filters were blocked by immersing in $50 \mathrm{mM}$ Tris, $\mathrm{pH} 7.4,150 \mathrm{mM} \mathrm{NaCl}$, and $0.05 \%$ Tween 20 (blocking buffer) containing $5 \%(\mathrm{w} / \mathrm{v})$ powdered milk for $3 \mathrm{~h}$ at room temperature, and then incubated overnight at $4^{\circ} \mathrm{C}$ with KRP2 $(1 / 1000)$ antibody in blocking buffer containing $1 \%(w / v)$ powdered milk. Antigenantibody complexes were detected with horseradish peroxidase-conjugated IgG diluted 1/5000 with an ECL chemiluminescence system.

\section{In vitro kinase assay}

P10 ${ }^{\text {CKS1At }}$-bound CDK activity was measured as described by De Veylder et al. [63] with modifications. CKS1At was purified from an overproducing strain of E. coli and linked to $\mathrm{CNBr}$-Sepharose $4 \mathrm{~B}$ at a concentration of $11 \mathrm{mg}$ protein per $1 \mathrm{~g}$ beads according to suppliers' instructions. Portions $(50 \mu \mathrm{l})$ of the resulting suspension of $\mathrm{p} 10^{\mathrm{CKS} 1 \mathrm{At}}$ Sepharose beads were washed with bead buffer $(50 \mathrm{mM}$ Tris, pH 7.4, $5 \mathrm{mM} \mathrm{NaF,} 250 \mathrm{mM} \mathrm{NaCl}, 5 \mathrm{mM}$ EDTA, $5 \mathrm{mM}$ EGTA, 0.1\% Nonidet P40, $20 \mu \mathrm{g} \mathrm{ml}^{-1}$ leupetin, $20 \mu \mathrm{g} \mathrm{ml}^{-1}$ aprotein, $100 \mu \mathrm{M}$ benzamidine and $1 \mathrm{mM}$ phenylmethylsulfonyl fluoride) and mixed with portions of the extracts, prepared as described above, containing $150 \mu \mathrm{g}$ protein in tubes that were then rotated constantly at $4^{\circ} \mathrm{C}$ for $3 \mathrm{~h}$. After a brief centrifugation at $5000 \mathrm{rpm}$ and removal of the supernatant, the beads were carefully washed three times with bead buffer, once with kinase buffer (50 mM HEPES, pH 7.5, $10 \mathrm{mM} \mathrm{MgCl}, 1 \mathrm{mM}$ dithiothreitol), and then used for kinase assays, as described by Hemerly et al. [45], with histone as CDK substrate.

\section{Accession number}

Nicotiana tabacum: [Actin2:U60495, CYCD3;1: AB015222, E2Fa:AB025347, H4:AB280787, CYCA1;1: D50735, CYCB1;1:Z37978, RBR:AB015221]

Arabidopsis thaliana: [PP2A:AY099760, CDKA;1: AB009399, CYCD3;1:NM_119579, CYCD3;2:NM_126126, CDKB1;1:D10851, CDKB2;1:NM_106304, E2Fa:AJ294534, DNA polymerase a:NM_126110, CDC6a:NM_128522, KRP1:NM_127907, KRP2:NM_114923] 


\section{Additional material}

Additional file 1: Table S1. Effects of NCS on epidermal cell size in Arabidopsis root. Table S2. Effects of phytohormones and NCS on primary root growth of Arabidopsis. Table S3. List of PCR primers used in the present study. Figure S1. Effects of NCS on relative growth rate and mitotic index of Arabidopsis root. Figure S2. Effects of NCS on cell differentiation of vascular cells. Figure S3. Recovery of the inhibition effects of NCS on root development. Figure S4. Physiological effects of NCS in Arabidopsis root.

\section{Abbreviations}

CDK: Cyclin-dependent kinases; KRP1: Kip-related protein1; KRP2: Kip-related protein2; MS: Murashige-Skoog; NCS: Narciclasine; ORC: Origin recognition complex; RBR: Retinoblastoma-related; RB: Retinoblastoma; qRT-PCR: Quantitative reverse transcription PCR; QC: Quite center; WT: Wild type.

\section{Acknowledgements}

The authors thank Drs. Xiao-Ya Chen for kindly providing CYCB1:1::uidA and CDKA; :::uidA seeds, Ben Scheres for QC25:: uidA seeds, Laurent Laplaze for J0121 seeds, Lieven De Veylder for E. coli cells, and Pascal Genschik for the KRP2 antibody. We thank Dr. Jiangqi Wen for comments on the manuscript. This work was financially supported by the National Natural Science Foundation of China (No. 30670191).

\section{Authors' contributions}

$\mathrm{XN}$ designed the studies, participated in the experiments and drafted the manuscript. YH carried out the immunoassays and histochemical analyses. KY participated in the q-RT-PCR. HL participated in the flow cytometry analysis. PJ helped to use the confocal microscope. HW and XW gave great suggestions for experiments and manuscript. YB conceived of the study, and participated in its design and coordination and helped to draft the manuscript. All authors read and approved the final manuscript.

\section{Competing interests}

The authors declare that they have no competing interests.

Received: 24 April 2011 Accepted: 28 December 2011 Published: 28 December 2011

\section{References}

1. Coffman J: Cell cycle development. Dev Cell 2004, 6:321-327.

2. Gutierrez C, Ramirez-Parra E, Castellano MM, del Pozo JC: G1 to S transition: more than a cell cycle engine switch. Curr Opin Plant Biol 2002, 5:480-486

3. Stevaux O, Dyson NJ: A revised picture of the E2F transcriptional network and RB function. Curr Opin Plant Biol 2002, 14:684-691.

4. Cooper S, Shayman JA: Revisiting retinoblastoma protein phosphorylation during the mammalian cell cycle. Cell Mol Life Sci 2001, 58:580-595.

5. De Veylder L, Joubès J, Inzé D: Plant cell cycle transitions. Curr Opin Plant Biol 2003, 6:536-543.

6. Dewitte W, Murray JAH: The plant cell cycle. Annu Rev Plant Biol 2003, 54:235-264.

7. Dewitte W, Riou-Khamlichi C, Scofield S, Healy JMS, Jacamard A, Kilby NJ, Murray JAH: Altered cell cycle distribution, hyperplasia, and inhibited differentiation in Arabidopsis caused by the D-type cyclin CYCD3. The Plant Cell 2003, 15:79-92.

8. Murray AW: Recycling the cell cycle cyclins revisited. Cell 2004, 116:221-234

9. Elledge SJ: Cell cycle checkpoints: preventing an identity crisis. Science 1996, 274:1664-1672

10. Nasmyth K: Viewpoint: putting the cell cycle in order. Science 1996, 274:1643-1645.

11. Mironov V, De Veylder L, Van Montagu M, Inzé D: Cyclin-dependent kinases and cell division in plants-the nexus. The Plant Cell 1999, 11:509-522.

12. Sherr CJ, Roberts JM: CDK inhibitors: positive and negative regulators of G1-phase progression. Genes Dev 1999, 13:1501-1512.
13. De Veylder L, Beeckman T, Beemster GTS, Krols L, Terras F, Landrieu I, Van Der Schueren E, Maes S, Naudts M, Inzé D: Functional analysis of cyclindependent kinase inhibitors of Arabidopsis. The Plant Cell 2001, 13:1653-1668.

14. Vandepoele K, Raes J, De Veylder L, Rouzé P, Rombauts S, Inzé D: Genomewide analysis of core cell cycle genes in Arabidopsis. The Plant Cell 2002, 14:903-916.

15. Wang H, Fowke LC: A plant cyclin-dependent kinase inhibitor gene. Nature 1997, 386:451-452.

16. Wang H, Qi Q, Schorr P, Cutler AJ, Crosby WL, Fowke LC: ICK1, a cyclindependent protein kinase inhibitor from Arabidopsis thaliana interacts with both Cdc2a and $\mathrm{CycD} 3$, and its expression is induced by abscisic acid. Plant J 1998, 15:501-510.

17. Wang H, Zhou Y, Gilmer S, Whitwill S, Fowke LC: Expression of the plant cyclin-dependent kinase inhibitor ICK1 affects cell division, plant growth and morphology. Plant J 2000, 24:613-623.

18. Zhou Y, Fowke LC, Wang H: Plant CDK inhibitors: studies of interactions with cell cycle regulators in the yeast two-hybrid system and functional comparisons in transgenic Arabidopsis plants. Plant Cell Rep 2002, 20:967-975.

19. Bastida J, Lavilla R, Viladomat F: Chemical and biological aspects of Narcissus alkaloids. In The Alkaloids Edited by: Cordell GA 2006, 3:87-179.

20. Piozzi F, Marino ML, Fuganti C, Martino AD: Occurrence of non-basic metabolites in Amaryllidaceae. Phytochemistry 1969, 8:1745-1748.

21. Ceriotti G: Narciclasine: an antimitotic substance from Narcissus bulbs Nature 1967, 213:595-596

22. Gabrielsen B, Monath TP, Huggins JW, Kefauver DF, Pettit GR, Groszek G, Hollingshead M, Kirsi JJ, Shannon WM, Schubert EM: Antiviral (RNA) activity of selected Amaryllidaceae isoquinoline constituents and synthesis of related substances. J Nat Prod 1992, 55:1569-1581.

23. Carrasco L, Fresno M, Vazquez D: Narciclasine: an antitumour alkaloid which blocks peptide bond formation by eukaryotic ribosomes. FEBS Lett 1975, 52:236-239.

24. Dumont $P$, Ingrassia L, Rouzeau S, Ribaucour F, Thomas S, Roland I, Darro F, Lefranc F, Kiss R: The Amaryllidaceae isocarbostyril narciclasine induces apoptosis by activation of the death receptor and/or mitochondrial pathways in cancer cells but not in normal fibroblasts. Neoplasia 2007, 9:766-776

25. Lefranc F, Sauvage S, Goietsenoven GV, Mégalizzi V, Lamoral-Theys D, Debeir O, Spiegl-Kreinecker S, Berger W, Mathieu V, Decaestecker C, Kiss R: Narciclasine, a plant growth modulator, activates Rho and stress fibers in glioblastoma cells. Mol Cancer Ther 2009, 8(7):1739-1750.

26. McLachlan A, Kekre N, McNulty J, Pancratistatin SPandey: A natural anticancer compound that targets mitochondria specifically in cancer cells to induce apoptosis. Apoptosis 2005, 10:619-630

27. Bi YR, Yung KH, Wong YH: Physiological effects of narciclasine from the mucilage of Narcissus tazetta L. bulbs. Plant Sci 1998, 135:103-108.

28. Bi YR, Zhang LX, Guo JK, Yung KH, Wong YH: Narciclasine alters chloroplast membrane structure and inhibits 5 -aminolevulinic acid and chlorophyll binding protein accumulation in wheat (Triticum aestivum) leaves. New Zealand J Crop Horti Sci 2003, 31:335-344.

29. Fleming AJ, McQueen-Mason S, Mandel T, Kuhlemeier C: Induction of leaf primordia by the cell wall protein expansin. Science 1997, 276:1415-1418

30. Taylor CB: Plant vegetative development: from seed and embryo to shoot and root. The Plant Cell 1997, 9:981-988.

31. Martinez MC, Jørgensen JE, Lawton MA, Lamb CJ, Doerner PW: Spatial pattern of $c d c 2$ expression in relation to meristem activity and cell proliferation during plant development. Proc Natl Acad Sci USA 1992, 89:7360-7364.

32. Himanen $K$, Boucheron E, Vanneste $S$, de A Engler J, Inzé D, Beeckman T: Auxin-mediated cell cycle activation during early lateral root initiation. The Plant Cell 2002, 14:2339-2351.

33. Ferreira PCG, Hemerly AS, Montagu MV, Inzé D: Control of cell proliferation during plant development. Plant Mol Biol 1994, 26:1289-1303.

34. Nagata T, Nemoto $Y$, Hasezawa S: Tobacco BY-2 cell line as the HeLa cell in the cell biology of higher plants. Int Rev Cytol 1992, 132:1-30.

35. Reichheld JP, Chaubet N, Shen WH, Renaudin JP, Gigot C: Multiple A-type cyclins express sequentially during the cell cycle in Nicotiana tabacum BY2 cells. Proc Natl Acad Sci USA 1996, 93:13819-13824

36. Dewitte W, Scofield S, Alcasabas AA, Maughan SC, Menges M, Braun N, Collins C, Nieuwland J, Prinsen E, Sundaresan V, Murray JAH: Arabidopsis 
$\mathrm{CYCD}_{3}$ D-type cyclins link cell proliferation and endocycles and are ratelimiting for cytokinin responses. Proc Natl Acad Sci USA 2007, 104:14537-14542.

37. Vandepoele K, Vlieghe K, Florquin K, Hennig L, Beemster GTS, Gruissem W, Van de Peer Y, Inzé D, De Veylder L: Genome-wide identification of potential plant E2F target genes. Plant Physiol 2005, 139:316-328.

38. Verkest A, Weinl C, Inzé D, De Veylder L, Schnittger A: Switching the Cell Cycle. Kip-Related Proteins in Plant Cell Cycle Control. Plant Physiol 2005, 139:1099-1106.

39. Verkest A, Manes CLO, Vercruysse S, Maes S, Van Der Schueren E, Beeckman T, Genschik P, Kuiper M, Inzé D, De Veylder L: The cyclindependent kinase inhibitor KRP2 controls the onset of the endoreduplication cycle during Arabidopsis leaf development through inhibition of mitotic CDKA; 1 kinase complexes. The Plant Cell 2005, 17:1723-1736.

40. Toorop PE, Barroco RM, Engler G, Groot SPC, Hilhorst HWM: Differentially expressed genes associated with dormancy or germination of Arabidopsis thaliana seeds. Planta 2005, 221:637-647.

41. Masubelele NH, Dewitte W, Menges M, Maughan S, Collins C, Huntley R, Nieuwland J, Scofield S, Murray JAH: D-type cyclins activate division in the root apex to promote seed germination in Arabidopsis. Proc Natl Acad Sci USA 2005, 102:15694-15699.

42. Inzé D: Green light for the cell cycle. EMBO J 2005, 24:657-662.

43. De Veylder L, Beeckman T, Beemster GTS, de Almeida Engle J, Ormenese S, Maes S, Naudts M, Van Der Schueren E, Jacamard A, Engler G, Inzé D: Control of proliferation, endoreduplication and differentiation by the Arabidopsis E2Fa-DPa transcription factor. EMBO J 2002, 21:1360-1368.

44. Boudolf $\mathrm{V}$, Barrôco R, de Almeida Engler J, Verkest A, Beeckman T, Naudts M, Inzé D, De Veylder L: B1-type cyclin-dependent kinases are essential for the formation of stomatal complexes in Arabidopsis thaliana. The Plant Cell 2004, 16:945-955.

45. Hemerly A, de A Engler J, Bergounioux C, Van Montagu M, Engler G, Inzé D, Ferreira $\mathrm{P}$ : Dominant negative mutants of the $\mathrm{Cdc} 2$ kinase uncouple cell division from iterative plant development. EMBO J 1995, 14:3925-3936.

46. Joubès J, De Schutter K, Verkest A, Inzé D, De Veylder L: Conditional, recombinase-mediated, expression of genes in plant cell cultures. Plant $J$ 2004, 37:889-896.

47. Porceddu A, Stals H, Reichheld JP, Segers G, De Veylder L, de Pinho Barrôco R, Casteels P, Van Montagu M, Inzé D, Mironov V: A plant-specific cyclin-dependent kinase is involved in the control of G2/M progression in plants. J Biol Chem 2001, 276:36354-36360.

48. Hirayama T, Imajuku Y, Anai T, Matsui M, Oka A: Identification of two cellcycle controlling cdc2 gene homologs in Arabidopsis thaliana. Gene 1991, 105:159-165.

49. Joubès J, Chevalier $C$, Dudits $D$, Heberle-Bors E, Inzé $D$, Umeda $M$ Renaudin JP: CDK-related protein kinases in plants. Plant Mol Biol 2000, 43:607-620.

50. Boudolf $\mathrm{V}$, Rombauts $\mathrm{S}$, Naudts $\mathrm{M}$, Inzé $\mathrm{D}$, De Veylder L: Identification of novel cyclin-dependent kinases interacting with the CKS1 protein of Arabidopsis. J Exp Bot 2001, 52:1381-1382.

51. Boudolf , Vlieghe K, Beemster GTS, Magyar Z, Acosta JAT, Maes S, Van Der Schueren E, Inzé $D$, De Veylder L: The plant-specific cyclin-dependent kinase CDKB1; 1 and transcription factor E2Fa-DPa control the balance of mitotically dividing and endoreduplicating cells in Arabidopsis. The Plant Cell 2004, 16:2683-2692

52. Foley $\mathrm{E}, \mathrm{O}$ 'Farrell $\mathrm{PH}$, Sprenger $\mathrm{F}$ : Rux is a cyclin dependent kinase inhibitor (CKI) specific for mitotic cyclin-Cdk complexes. Curr Biol 1999, 9:1392-1402

53. Foley E, Sprenger F: The cyclin-dependent kinase inhibitor Roughex is involved in mitotic exit in Drosophila. Curr Biol 2001, 11:151-160.

54. Stern B, Nurse P: A quantitative model for the $\mathrm{cdc} 2$ control of $\mathrm{S}$ phase and mitosis in fission yeast. Trends Genet 1996, 12:345-350.

55. Schnittger A, Weinl C, Bouyer D, Schöbinger U, Hülskamp M: Misexpression of the cyclin-dependent kinase inhibitor ICK1/KRP1 in single-celled Arabidopsis trichomes reduces endoreduplication and cell size and induces cell death. The Plant Cell 2003, 15:303-315.

56. Weinl C, Marquardt S, Kuijt SJH, Nowack MK, Jakoby MJ, Hülskamp M, Schnittger A: Novel functions of plant cyclin-dependent kinase inhibitors, ICK1/KRP1, can act non-cell-autonomously and inhibit entry into mitosis. The Plant Cell 2005, 17:1704-1722.
57. Na XF, Hu YF, Yue K, Lu HX, Jia PF, Wang HH, Wang XM, Bi YR: Narciclasine modulates polar auxin transport in Arabidopsis roots. I of Plant Physiology 2011, 168:1149-1156.

58. Casimiro I, Marchant A, Bhalerao R, Beeckman T, Dhooge S, Swarup R, Grahamb N, Inzé D, Sandbergc G, Caseroa PJ, Bennett M: Auxin transport promotes Arabidopsis lateral root initiation. The Plant Cell 2001, 13:843-852.

59. Masucci J, Schiefelbein J: The rhd6 mutation of Arabidopsis thaliana alters root-hair initiation through an auxin-and ethylene-associated process. Plant Physiology 1994, 106:1335-1346.

60. Galbraith DW, Harkins KR, Maddox JM, Ayres NM, Sharma DP, Firoozabady E: Rapid flow cytometric analysis of the cell cycle in intact plant tissues. Science 1983, 220:1049-1051.

61. Jefferson RA, Kavanagh TA, Bevan MW: GUS fusions: beta-glucuronidase as a sensitive and versatile gene fusion marker in higher plants. EMBO $J$ 1987, 6:3901-3907.

62. Willemsen V, Wolkenfelt $H$, de Vrieze G, Weisbeek P, Scheres B: The HOBBIT gene is required for formation of the root meristem in the Arabidopsis embryo. Development 1998, 125:521-531.

63. De Veylder L, Segers G, Glab N, Casteels P, Van Montagu M, Inzé D: The Arabidopsis Cks1At protein binds the cyclin-dependent kinases Cdc2aAt and Cdc2bAt. FEBS Lett 1997, 412:446-452.

doi:10.1186/1471-2229-11-184

Cite this article as: $\mathrm{Na}$ et al: Concentration-dependent effects of narciclasine on cell cycle progression in Arabidopsis root tips. BMC Plant Biology 2011 11:184.

\section{Submit your next manuscript to BioMed Central and take full advantage of:}

- Convenient online submission

- Thorough peer review

- No space constraints or color figure charges

- Immediate publication on acceptance

- Inclusion in PubMed, CAS, Scopus and Google Scholar

- Research which is freely available for redistribution

Submit your manuscript at www.biomedcentral.com/submit
Ciomed Central 